\title{
A AUTONOMIA CIENTÍFICA DO CONTROLE ABSTRATO DE CONSTITUCIONALIDADE E SUA APLICAÇÃO PELO SUPREMO TRIBUNAL FEDERAL
}

\author{
THE SCIENTIFIC AUTONOMY OF THE ABSTRACT CONTROL OF \\ CONSTITUTIONALITY AND ITS APPLICATION BY THE SUPREME \\ COURT
}

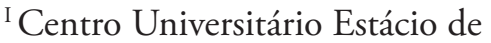
Ribeirão Preto/SP, Ribeirão Preto, SP, Brasil. Doutor em Direitos Coletivos.

E-mail: dhnunes@hotmail.com
}

${ }^{\text {II }}$ Centro Universitário Estácio de Ribeirão Preto/SP, Ribeirão Preto, SP, Brasil. Mestre em Direitos Coletivos. E-mail: joaopedrosilvestrini@hotmail. com

${ }^{\text {III }}$ Universidade de Ribeirão Preto, Ribeirão Preto, SP, Brasil. Doutor em Direito. E-mail: olavoferreira@hotmail. com

\author{
Danilo Henrique Nunes ${ }^{\mathrm{I}}$ \\ João Pedro Silvestrini ${ }^{\text {II }}$ \\ Olavo Augusto Vianna Alves Ferreira ${ }^{\text {III }}$
}

\begin{abstract}
Resumo: Este trabalho consiste em uma pesquisa acerca da autonomia do controle abstrato, em virtude de sua natureza objetiva. Nesse sentido, o objetivo pretendido é a discussão referente à subsistência da autonomia científica do controle abstrato de constitucionalidade e investigar sua aplicação pelo Supremo Tribunal Federal. A fiscalização normativa abstrata visa a tutela da ordem constitucional, não se vinculando a uma situaçáo jurídica de caráter individual ou concreto. Assim, não se mostra conveniente o emprego de normas subjetivas a um processo objetivo, pois ocasionaria na utilização de normas processuais impertinentes e, consequentemente, impróprias. Portanto, em decorrência da especificidade e da consequente independência do processo objetivo, constata-se a existência da autonomia científica da fiscalizaçáo abstrata de constitucionalidade. Esse é o entendimento adotado pelo Supremo Tribunal Federal, conforme o julgado nas Açóes Direitas de Inconstitucionalidade $\mathrm{n}^{\circ} 1.254 / \mathrm{RJ}, \mathrm{n}^{\circ} 3.345 /$ DF e no $2.422 / D F$. Logo, mediante uma pesquisa dedutiva, baseada em estudos na jurisprudência do Supremo Tribunal Federal, na doutrina e ao anteprojeto de Código de Processo Constitucional (assumido pela Ordem dos Advogados do Brasil), o presente trabalho sustentará a tese referente à emancipação do direito processual constitucional abstrato.
\end{abstract}

Palavras-chave: Controle abstrato de constitucionalidade; Processo objetivo; Autonomia científica.

Abstract: This work consists of a research about the autonomy of abstract control, by virtue of its objective nature. In this sense, the intended objective is the discussion regarding the subsistence of the scientific autonomy of the abstract control of constitutionality and investigates its application by the

Recebido em: 09/12/2021

Aceito em: 11/12/2021 
Supreme Court. The abstract normative inspection aims at protecting the constitutional order, not being linked to a juridical situation of individual or concrete character. Thus, it is not appropriate to use subjective norms to an objective process, because it would lead to the use of impertinent and consequently inappropriate procedural rules. Therefore, due to the specificity and consequent independence of the objective process, the existence of the scientific autonomy of the abstract review of constitutionality is verified. This is the understanding adopted by the Federal Supreme Court, as judged in the Right Share of Unconstitutionality n. 1.254/ RJ, n. 3.345/DF and n. 2.422/DF. Therefore, through a deductive research, based on studies in the jurisprudence of the Federal Supreme Court, in the doctrine and to the preliminary draft of the Code of Constitutional Process (assumed by the Brazilian Bar Association), this paper will support the thesis regarding the emancipation of constitutional procedural law abstract.

Keywords: Abstract control of constitutionality; Objective process; Scientific autonomy.

\section{Introdução}

Tnegável a evolução do controle abstrato de constitucionalidade ocorrida após a Constituição de 1988, que promoveu a ampliação da legitimidade da Ação Direta de Inconstitucionalidade, previu a Ação Direta de Inconstitucionalidade por Omissão e Arguição de Descumprimento de Preceito Fundamental, além da criação da Ação Declaratória de Constitucionalidade pela Emenda Constitucional no 3/93, culminando na edição das Leis $n^{\circ}$ 9.868/99 e no 9.882/99.

A Lei no 9.868, de 10 de novembro de 1999, disciplinou, perante a Suprema Corte, o processo e julgamento da Ação Direta de Inconstitucionalidade e da Açáo Declaratória de Constitucionalidade (BARROSO, 2016). Por sua vez, a Lei no 9.882, de 03 de dezembro de 1999, regulamentou o processo e julgamento da Arguição de Descumprimento de Preceito Fundamental, que até este momento permanecera como letra morta (BARROSO, 2016).

Recentes julgados do Supremo Tribunal Federal ${ }^{1}$ justificam a relevância do debate em torno da autonomia científica do controle abstrato de constitucionalidade, resultante das influências indevidas, que o direito processual constitucional de natureza objetiva recebe dos ramos do direito processual de natureza subjetiva (LUNARDI, 2013), investigando se este Tribunal adota a autonomia ou não e quais os fundamentos técnicos empregados, analisando as posiçóes adotadas e apresentando propostas.

Por outro ângulo, a questão acerca da indagação da autonomia científica não deve ser apreciada de maneira estática, mas em sua perspectiva temporal, analisando se o processo

1 STF - ARE: 827511/PR, rel. Min. Celso de Mello, data de julgamento: 21/10/2014; ADI no 2.422/DF, rel. Min. Celso de Mello, data de julgamento: 10/05/2012; ADI no 1.254/RJ, rel. Min. Celso de Mello, data de julgamento: 14/08/1996; ADI no 3.345/DF, rel. Min. Celso de Mello, data de julgamento: 25/08/2005. 
constitucional abstrato logrou êxito em delimitar e diferenciar nitidamente seus conceitos e conteúdo normativo, bem como se emancipar (BERNARDES, 2004) dos outros ramos processuais (LUNARDI, 2013).

Logo, mediante uma pesquisa dedutiva, baseada em estudos na jurisprudência do Supremo Tribunal Federal e na doutrina, o presente trabalho sustentará a tese referente à emancipação do direito processual constitucional abstrato. Mais especificamente, afirmará a autonomia científica da fiscalização abstrata de constitucionalidade, por configurar típico atributo de um procedimento de natureza objetiva.

\section{Da supremacia da Constituiçáo e o controle de constitucionalidade para sua manutençáo}

O controle de constitucionalidade consiste no conjunto de mecanismos aptos a assegurar a supremacia constitucional, mediante a identificação e eventual retificação de condutas incompatíveis com determinadas normas constitucionais (BERNARDES, 2004). "Nesse sistema normativo, a Constituição de um Estado é a norma suprema, ou seja, fundamental, pois nela é que buscamos a validade das normas existentes no ordenamento jurídico" (MARIA; MARCEDO, 1999, p. 41).

A compreensão da Constituição como Lei Fundamental ocasiona tanto no reconhecimento de sua supremacia na ordem jurídica, bem como na subsistência de técnicas capazes de confirmála juridicamente (CLÈVE, 2000). Para tanto, é inexorável que essa esteja acompanhada da "vontade de Constituiçâo"2, ou melhor, de uma certa "consciência constitucional" (CLÈVE, 2000, p. 33), a qual "reclama a defesa permanente da obra e dos valores adotados pelo Poder Constituinte” (CLÈVE, 2000, p. 33).

Nesse sentido, Hans Kelsen assevera que:

a ordem jurídica não é um sistema de normas jurídicas ordenadas no mesmo plano, situadas umas ao lado das outras, mas é uma construção escalonada de diferentes camadas ou níveis de normas jurídicas. A sua unidade é produto da conexão de dependência que resulta do fato de a validade de uma norma, que foi produzida de acordo com outra norma, se apoiar sobre essa outra norma, cuja produção, por sua vez, é determinada por outra; e assim por diante, até abicar finalmente na norma fundamental - pressuposta. A norma fundamental - hipotética, nestes termos - é, portanto, o fundamento de validade último que constitui a unidade desta interconexão criadora. (KELSEN, 1987, p. 240).

Logo, conforme a teoria do escalonamento normativo elaborado por Hans Kelsen (1987), compreende-se que a Constituição corresponde à norma de maior hierarquia de nosso ordenamento jurídico, pois concede validade e unidade às demais normas jurídicas que compóem seu sistema (SIQUEIRA JR., 2017).

2 Conforme Konrad Hesse, a vontade de Constituição baseia-se: a) na compreensão da necessidade e do valor de uma ordem normativa que proteja o Estado contra arbítrios; b) na compreensão que a ordem constituída é mais que uma ordem legitimada pelos fatos; c) na compreensão de que a norma não será eficaz sem o concurso da vontade humana (A Força Normativa da Constituiçáo. Tradução de Gilmar Ferreira Mendes. Porto Alegre: SAFE, 1991. p. $19-20)$. 
Portanto, por encontrar-se no vértice do sistema normativo, a Constituição possui supremacia sobre as demais normas jurídicas, carecendo, assim, de respeito integral, pois constitui-se em Lei Suprema tanto na perspectiva formal quanto na material.

No que se refere à perspectiva formal, "a Constituição possui força jurídica superior àquela das demais normas do ordenamento jurídico" (DIMOULIS; LUNARDI, 2013, p. 18). No tocante à ótica material, a Constituição possui supremacia pois tutela os dogmas fundamentais do $E_{s t a d o}{ }^{3}$, e também por expressar um projeto político que é elaborado pelos detentores do poder, estabelecendo, sistematicamente, e de modo claro e taxativo, a ordem política do Estado (DIMOULIS; LUNARDI, 2013).

Assim, a caracterização do princípio da hierarquia normativa é imprescindível para o exercício do controle de constitucionalidade, uma vez que não há a probabilidade de se verificar uma instrução normativa na concepção de outro comando de igual hierarquia jurídica (VAINER, 2009).

"Em outras palavras, só se pode controlar a constitucionalidade de determinado ato normativo se o parâmetro do controle (a Constituição) for superior a este ato" (VAINER, 2009, p. 56).

Por consequência, com o fito de prevenir distinçôes em um ordenamento jurídico, requer-se que nenhuma regra infraconstitucional contradiga e discrimine as normas e princípios da Constituição de um Estado, em nome de sua hegemonia (VAINER, 2009).

Ainda, resta averiguado que o controle dos atos emanados do Poder Legislativo ocorre unicamente por meio da adequaçáo desses à uma Constituição que se encontra situada em um patamar superior (VAINER, 2009), e, a qual é caracterizada por sua rigidez ${ }^{4}$.

Enfim, em decorrência da supremacia das normas constitucionais, faz-se imprescindível a pertinência, inclusive pelas emendas à Constituição Federal, daquilo que está expresso no texto constitucional, sob pena de configuração do vício de inconstitucionalidade (CALCINI, 2009).

\section{Espécies de controle jurisdicional repressivo de constitucionalidade}

Considerado como instrumento substancial do Estado de Direito, o controle de constitucionalidade, como instituto do direito processual constitucional, consiste em método propício para que seja possível garantir as disposiçôes estabelecidas na Constituição Federal de 1988 (SIQUEIRA JR., 2017).

Este mecanismo constitucional visa impedir, em nosso ordenamento jurídico, a "existência de atos normativos contrários à Constituição e ao próprio Estado de Direito consagrado no

3 Isto é, os direitos fundamentais e a organização dos poderes.

4 "A rigidez constitucional decorre da maior dificuldade para sua modificação do que para a alteração das demais normas jurídicas da ordenação estatal” (SILVA, José Afonso da. Curso de Direito Constitucional Positivo. 36. ed. rev. e atual. São Paulo: Malheiros, 2013. p. 47). Isto é, a rigidez garante às normas constitucionais uma capacidade de resistência à derrogação superior das leis ordinárias, sendo que, desta forma, a Constituição será revisada apenas mediante um procedimento específico, e de acordo com os limites formais, circunstanciais e materiais desta (CANOTILHO, J. J. Gomes. Direito Constitucional e Teoria da Constituiçáo. 7. ed. Coimbra: Almedina, 2007. p. 215). 
texto constitucional. Este é o cerne do controle de constitucionalidade e num sentido amplo do próprio direito processual constitucional" (SIQUEIRA JR., 2017, p. 97).

No sistema jurídico pátrio ${ }^{5}$, o controle de constitucionalidade éhíbrido (VELOSO, 2003), sendo que neste há dois mecanismos ou sistemas de controle repressivo de constitucionalidade ${ }^{6}$ : "o concentrado (ou reservado, ou via de ação, ou direto); e o difuso (ou aberto, ou via de exceção ou defesa, ou descentralizado)" (FERREIRA, 2016, p. 38). Ambos serão discutidos no decorrer deste trabalho.

Contudo, faz-se necessário ressaltar, previamente, que o controle abstrato e o controle concentrado de constitucionalidade constituem modalidades distintas, não sendo passível, neste ponto, qualquer confusão entre estes procedimentos.

O controle abstrato consiste em processo de natureza típica objetiva ${ }^{7}$, que não possui contraditório (VELOSO, 2003), uma vez que inexistem partes, muito embora possam ser consultados órgáos que participaram da elaboração da lei que está sendo discutida perante o Supremo Tribunal Federal, bem como outros atores envolvidos ativamente no ciclo deste procedimento (LUNARDI, 2013).

Ademais, pode ser instaurado "independentemente da demonstração da existência de um interesse jurídico específico” (MENDES, 1994, p. 53), "configurando típico processo objetivo, cuja finalidade é a preservação da ordem jurídica" (FERREIRA, 2016, p. 38).

São ações do controle abstrato de constitucionalidade: (a) a Ação Declaratória de Constitucionalidade; (b) a Ação Direta de Inconstitucionalidade por Ação; (c) a Ação Direta de Inconstitucionalidade por Omissão; e (d) a Arguição de Descumprimento de Preceito Fundamental.

De maneira oposta, o controle concentrado, que é exercido diretamente no Pretório Excelso ${ }^{8}$, nem sempre é abstrato, compreendendo: (a) a Ação Declaratória de Constitucionalidade; (b) a Ação Direta de Inconstitucionalidade por Ação; (c) a Ação Direta de Inconstitucionalidade por Omissão; e (d) a Ação Direta Interventiva.

Constata-se que a Ação Direta Interventiva não figura ao rol das açóes do controle abstrato de constitucionalidade, pois "não desencadeia um processo objetivo" (CLÈVE, 2000, p. 128), visto que o "objeto do processo não é a declaraçáo da inconstitucionalidade em tese de um ato estadual, mas antes a solução de um conflito entre a Uniáo e o Estado-membro que pode

5 "A Constituição é norma fundamental do sistema jurídico em dois sentidos. Num plano a Constituição é a norma criadora, fundante do sistema jurídicos. Em outro aspecto, é a viga mestra, a espinha dorsal do sistema jurídico, ou seja, seu fundamento de validade” (SIQUEIRA JR., Paulo Hamilton. Direito Processual Constitucional. 7. ed. São Paulo: Saraiva, 2017. p. 100).

6 "O objeto deste controle pelo Judiciário são leis, ou atos normativos ou atos do poder público já editados. Vale lembrar que a doutrina trata do controle preventivo de constitucionalidade e dos órgáos controladores" (BONIZZI, Marcelo José Magalhães; FERREIRA, Olavo Augusto Vianna Alves. Declaração de Inconstitucionalidade pelo Árbitro: Vedação ou Dever. Revista de Processo, v. 274, p. 543 - 578, dez. 2017.

7 Processo objetivo é aquele que possui como única finalidade constitucional a defesa do ordenamento jurídico, no tocante à sua hierarquia normativa (LUNARDI, Soraya. Teoria do Processo Constitucional: Análise de sua Autonomia, Natureza e Elementos. São Paulo: Atlas, 2013. p. 27).

8 Salvo a Ação Direta de Inconstitucionalidade no âmbito estadual, prevista no artigo $125, \$ 2^{\circ}$, da Constituição Federal de 1988: "Art. 125. Os Estados organizarão sua Justiça, observados os princípios estabelecidos nesta Constituição" ... " $\$ 2$ Cabe aos Estados a instituição de representação de inconstitucionalidade de leis ou atos normativos estaduais ou municipais em face da Constituição Estadual, vedada a atribuição da legitimação para agir a um único órgão”. 
desembocar numa intervenção" (CLÈVE, 2000, p. 129). Nesta ação do controle concentrado de constitucionalidade compete ao Supremo Tribunal Federal o julgamento de um conflito federativo, sendo que esta ação não tem por propósito a declaração de nulidade de lei ou ato do Poder Público, mas sim a decretação de intervenção federal (FERREIRA, 2016).

\subsection{Do Controle Difuso de Constitucionalidade no Brasil}

O controle difuso de constitucionalidade é aquele que sobrevém incidentalmente no curso de um processo comum (SIQUEIRA JR., 2017), caracterizando-se, assim, pela possibilidade de que qualquer Juiz ou Tribunal possa reconhecer a inconstitucionalidade de uma norma a qual foi arguida pela parte como modalidade de defesa (BARROSO, 2016).

Assim sendo, "o objeto principal da ação não é a inconstitucionalidade de lei ou ato normativo, sendo a mesma analisada incidentalmente ao julgamento de mérito” (SIQUEIRA JR., 2017, p. 149). Por consequência, com o intuito de solucionar o caso concreto em questão, faz-se necessária a declaração de inconstitucionalidade, já que essa pode decidir determinada relação jurídica que é o objeto principal da ação (SIQUEIRA JR., 2017).

Diversamente, no controle concentrado a fiscalização de constitucionalidade concentrase apenas em um único órgão (RAMOS, 1994).

A origem do controle de constitucionalidade difuso decorre do direito americano", na resolução do famoso caso William Marburry vs James Madison ${ }^{10}$, em que ficou assentada a responsabilidade do Tribunal no exercício do controle de constitucionalidade ${ }^{11}$.

Nesse pleito, o Juiz da Suprema Corte John Marshall, no ano de 1803, determinou que na hipótese de haver conflito entre a Lei e a Constituição, deve prevalecer essa última.

Elival da Silva Ramos salienta que:

antes mesmo de a Suprema Corte firmar entendimento favorável ao controle, o que somente aconteceu e 1803, no célebre caso 'Marbury versus Madison', os Tribunais Federais de Apelaçấo (Cortes de Circuito) já declaravam que um ato legislativo em contraste com uma norma constitucional deve ser apartado e rechaçado por incompatibilidade $\left(\right.$ RAMOS, 1994, p. 103) ${ }^{12}$.

9 "Além dos Estados Unidos, adotam o modelo de controle difuso na atualidade países como a Argentina, a Grécia e o Japão" (DIMOULIS, Dimitri; LUNARDI, Soraya. Curso de Processo Constitucional: controle de constitucionalidade e remédios constitucionais. 2. ed. São Paulo: Atlas, 2013. p. 73).

10 "A ideia de controle de constitucionalidade realizado por todos os órgãos do Poder Judiciário nasceu no caso Madison vs Marbury (1803), em que o Juiz Marshall da Suprema Corte Americana afirmou que é próprio da atividade jurisdicional interpretar e aplicar a lei. E ao fazê-lo, em caso de contradição entre a legislaçáo e a Constituição, o tribunal deve aplicar esta última por ser superior a qualquer lei ordinária do Poder Legislativo" (MORAES, Alexandre de. Direito Constitucional. 15. ed. São Paulo: Atlas, 2004. p. 608).

11 "O controle de constitucionalidade (judicial review) é exemplo da criatividade constitucional norte-americana. Trata-se do poder que o Judiciário tem de rever as açóes dos outros corpos governamentais, constatando (ou não) compatibilidade constitucional. Apoia-se concretamente no caso Marbury vs. Madison, julgado em 1803. Não há previsão constitucional quanto ao exercício do controle de constitucionalidade; a atividade não fora originariamente outorgada à Suprema Corte norte-americana. Não se cogitou do controle de constitucionalidade como inerente ao Poder Judiciário" (GODOY, Arnaldo Sampaio de Moraes. Direito nos Estados Unidos. Barueri: Manole, 2004. p. 64).

12 Na nota de rodapé n. 223, o citado autor afirma: "Ghigliani menciona decisão de uma Corte Federal de Circuito datada de 1795 e relatada pelo Juiz Patterson, que à época também fazia parte da Suprema Corte", acrescentando outras decisóes anteriores como no caso "Ware v. Hylton”, em que uma lei do Estado da Vírginia tinha sido declarada inconstitucional (nota de rodapé n. 228, p. 104). 
Por sua vez, Ronaldo Polleti enfatiza:

A Justiça do Estado de New Jersey, em 1780, declarou nula uma lei por contrariar ela a Constituição do Estado. Desde 1782, os juízes da Virgínia julgavam-se competentes para dizer da constitucionalidade das leis. Em 1787, a Suprema Corte da Carolina do Norte invalidou lei pelo fato de ela colidir com os artigos da Confederaçáo (POLLETI, 1985 , p. 36) ${ }^{13}$.

Depreende-se, pelo exposto, que no direito norte-americano o controle judicial da constitucionalidade é difuso, sendo que a decisão final é julgada pela Suprema Corte. No Brasil, o controle difuso está presente desde a primeira Constituição Republicana, subsistindo hodiernamente sem maiores modificaçóes (BARROSO, 2016).

Ademais, impede ressaltar pela inexequibilidade de confusão entre o controle incidental ${ }^{14}$ para o controle difuso.

"Há possibilidade de controle incidental no controle concentrado, como por exemplo na Ação Declaratória de Constitucionalidade no 1-1/DF” (FERREIRA, 2016, p. 41). Previamente análise do mérito da ação (constitucionalidade ou não de determinada norma), a Suprema Corte decidiu, em sede de controle incidental, pela constitucionalidade da Ação Declaratória (prevista por Emenda Constitucional) (STF - Pleno, Ação Declaratória de Constitucionalidade n. 1-1/ DF, Rel. Moreira Alves, Diário da Justiça, Seção I, 5 de novembro de 1993, p. 23.286, vencido o Ministro Marco Aurélio), tendo sido o mérito apreciado posteriormente.

No controle incidental ${ }^{15}$, a inconstitucionalidade é suscitada incidentalmente, em processo cujo objeto corresponde à questão diversa, estabelecendo-se na técnica processual matéria prejudicial (RAMOS, 1994), e que pertence à motivação do decisium, em julgamento incidenter tantum (FERREIRA, 2016). O controle difuso difere do controle em via de ação principal, em que o "objeto do processo é o próprio ato arguido de inconstitucional" (RAMOS, 1994, p. 98).

Todavia, o controle difuso será, em todo caso, incidental, uma vez que a "questão principal não poderá ser a questão constitucional, sob pena de ausência de interesse de agir (ausência do requisito necessidade da tutela jurisdicional, para solucionar o mal alegado), manifestada pela inexistência do caso concreto" (FERREIRA, 2016, p. 42).

Pois bem. A fiscalização jurisdicional difusa e incidental de constitucionalidade processarse-á na resolução do caso concreto, no qual, para tutelar-se determinado direito subjetivo, se afirmará ou se negará a aplicação a preceito normativo, a sujeitar-se do juízo afirmativo ou negativo de sua compatibilidade com a Carta Maior (ZAVASCKI, 2017, p. 23 - 24). Nessa conjectura, a força vinculante resultante do exame de constitucionalidade se limitará ao próprio

13 Sobre o assunto vide Blaine Free Moore, The Supreme Court and unconstitutional legislation, Studies in History, Economics and Public Law (volume LIV, n. 2, p. 13).

14 Vale dizer que no direito americano, o controle difuso é exercido somente em via incidental (judicial review, literalmente "verificação constitucional") (LUNARDI, Soraya. Teoria do Processo Constitucional: Análise de sua Autonomia, Natureza e Elementos. São Paulo: Atlas, 2013. p. 50).

15 Também chamado de controle por via de exceção ou defesa, pois usualmente a inconstitucionalidade era invocada pela parte demandada, que visava escusar-se do cumprimento de norma que não acreditava ser válida (BARROSO, Luís Roberto. O Controle de Constitucionalidade no Direito Brasileiro. 7. ed. rev. e atual. Sáo Paulo: Saraiva, 2016. p. 72). 
caso concreto (ZAVASCKI, 2017), mantendo-se a norma impugnada como sendo obrigatória a terceiros (SIQUEIRA JR., 2017).

Isto posto, Temer enumera características acerca da fiscalização difusa de constitucionalidade:

1. só é exercitável à vista do caso concreto, de litígio posto em juízo; 2. o juiz singular poderá declarar a inconstitucionalidade de ato normativo ao solucionar o litígio entre as partes; 3. não é declaração de inconstitucionalidade de lei em tese, mas exigência imposta para a solução do caso concreto; 4. a declaração, portanto, não é o objetivo principal da lide, mas incidente, consequência (TEMER, 1998, p. 43).

Deve-se destacar, também, que o controle difuso poderá ser exercido de ofício, conforme já decidiu o Supremo Tribunal Federal: "Ao Supremo Tribunal Federal, como guardiāo maior da Constituição, incumbe declarar a inconstitucionalidade de lei, sempre que esta se verificar, ainda que ex officio, em razão do controle difuso, independente de pedido expresso da parte" ${ }^{16}$.

Há, inclusive, precedente da Suprema Corte que afastou o prequestionamento ${ }^{17}$, adotando a causa de pedir aberta no Recurso Extraordinário, com a justificativa que compete ao Pretório Excelso a guarda da Constituição (artigo 102, caput, da Carta Magna de 1988) (FERREIRA, 2016).

O novo Código de Processo Civil consagrou esta tese em seu artigo $1.034^{18}$.

Em suma, em Recurso Extraordinário, o Supremo Tribunal Federal poderá exercer o controle difuso de ofício sem a observância do prequestionamento, pois essa Corte é a guardiã da supremacia constitucional. É aplicável, nessa situação, o artigo 10, do novo Código de Processo Civil $^{19}$, o qual dispóe, pela homenagem ao contraditório, que configura obrigação do magistrado, sob pena de nulidade.

Além disso, segundo a exigência do artigo 93, inciso IX, da Constituição Federal de $1988^{20}$, a motivação da declaração de inconstitucionalidade é imprescindível em todas as modalidades de controle de constitucionalidade.

Ainda, José Afonso da Silva (1998, p. 173) acentua a importância da fiscalização difusa de constitucionalidade, elucidando que somente o controle concentrado "não seria suficiente para a organização de um sistema eficaz de proteção aos direitos humanos, pois tal competência” já competia ao Supremo Tribunal Federal, "no regime das Constituiçóes anteriores, e não raro, lamentavelmente, suas decisôes sustentaram o arbítrio do regime militar” (SILVA, 1998, p. 173).

16 Informativo n. 365, do Supremo Tribunal Federal.

17 Neste sentido: STF, RE n. 298.694/SP.

18 "Art. 1.034. Admitido o recurso extraordinário ou o recurso especial, o Supremo Tribunal Federal ou o Superior Tribunal de Justiça julgará o processo, aplicando o direito. Parágrafo único. Admitido o recurso extraordinário ou o recurso especial por um fundamento, devolve-se ao tribunal superior o conhecimento dos demais fundamentos para a solução do capítulo impugnado”.

19 "Art. 10. O juiz não pode decidir, em grau algum de jurisdição, com base em fundamento a respeito do qual não se tenha dado às partes oportunidade de se manifestar, ainda que se trate de matéria sobre a qual deva decidir de ofício".

20 "Art. 93. Lei complementar, de iniciativa do Supremo Tribunal Federal, disporá sobre o Estatuto da Magistratura, observados os seguintes princípios:" ... "IX todos os julgamentos dos órgãos do Poder Judiciário serão públicos, e fundamentadas todas as decisóes, sob pena de nulidade, podendo a lei limitar a presença, em determinados atos, às próprias partes e a seus advogados, ou somente a estes, em casos nos quais a preservaçáo do direito à intimidade do interessado no sigilo náo prejudique o interesse público à informação". 
Enfim, o controle difuso de constitucionalidade pode ser realizado em qualquer ação, mesmo nos instrumentos da chamada "jurisdição constitucional da liberdade" 21 , que são "meios processuais constitucionais que objetivam o amparo dos direitos humanos" (SILVA, 1998, p. 175); ou mesmo em ação de competência originária, tendo como exemplo o Mandado de Segurança, o Mandado de Injunção, o Habeas Corpus e a Ação Originária ${ }^{22}$.

\subsection{Controle Abstrato de Constitucionalidade}

De maneira oposta, objetiva-se na fiscalização abstrata de constitucionalidade a declaração de inconstitucionalidade de um ato normativo ${ }^{23} \mathrm{em}$ tese, neste âmbito seja por ação ou omissão ${ }^{24}$, independentemente da existência de uma lide. Esse controle tem por função a retirada da norma inconstitucional do ordenamento jurídico, anteriormente à subsistência de um conflito interindividual e/ou social que exija sua aplicação (MARTINS, 2018).

Nessa via de controle, o próprio pedido da ação intentada será a inconstitucionalidade do ato normativo primário, que deverá ser declarada no dispositivo da decisão.

Em nosso ordenamento jurídico, o controle abstrato de constitucionalidade decorreu da Constituição de 1946 (BERNARDES, 2004). Em virtude do projeto de reforma constitucional idealizado com o intuito de deter a "sobrecarga imposta ao Supremo Tribunal Federal e ao Tribunal Federal de Recursos” (MENDES, 1990, p. 189), sucedeu a Emenda Constitucional no 16, de 26 de novembro de 1965, a qual instituiu a "representaçáo de lei ou ato de natureza normativa, federal ou estadual, encaminhada pelo Procurador Geral da República”25.

Dessa forma, ao contrário da então presente representação interventiva, figurou na competência da Suprema Corte "nova ação destinada a decidir em tesa da constitucionalidade de atos normativos, sem que houvesse qualquer preocupação com questóes conflituosas" (BERNARDES, 2004, p. 86).

Posteriormente, não sobreveio qualquer inovação referente à representação elaborada pela Emenda Constitucional no 16, de 26 de novembro de 1965, nos regimes originais das Constituiçôes de 1967 e 1969 (BERNARDES, 2004).

Contudo, foram abolidas as representaçôes de inconstitucionalidade da competência dos Tribunais de Justiça (MENDES, 1990). Em contrapartida, a Emenda Constitucional no 7,de 13 de abril de 1977, trouxe a representação para a interpretação de lei ${ }^{26}$, e ainda confirmou jurisprudência do Supremo Tribunal Federal ${ }^{27}$ acerca da admissibilidade de medida cautelar nas representaçôes de inconstitucionalidade ${ }^{28}$.

Com o avento da Constituição Federal de 1988, o complexo sistema brasileiro de fiscalização abstrata de constitucionalidade foi consolidado e otimizado (BERNARDES, 2004).

21 "São eles o habeas corpus, o mandado de segurança, a ação popular, o mandado de injunção, o habeas-data, e a ação civil pública” (FERREIRA, Olavo Augusto Vianna Alves. Controle de Constitucionalidade e seus Efeitos, op. cit., p. 44).

22 Por exemplo, aquelas previstas no artigo 102, I, alíneas "e", "f” e " $\mathrm{n}$ ".

23 Igualmente ao ato do poder público via arguição de descumprimento de preceito fundamental.

24 De inconstitucionalidade.

25 Artigo 101, inciso I, alínea "k", da Constituição de 1946.

26 Artigo 119, inciso I, alínea "l", da Constituição de 1969.

27 Representação n. 933/RJ, rel. Min. Thompson Flores, DJU de 26/12/1976 e RTJ, 76:342.

28 Artigo 119, inciso I, alínea "p", da Constituição de 1969. 
Atualmente, o controle abstrato consiste em processo de natureza objetiva, que não possui contraditório (VELOSO, 2003), já que também não há partes, embora possam ser consultados órgãos que participaram da elaboração da lei que está sendo discutida perante o Supremo Tribunal Federal, bem como outros atores envolvidos ativamente no ciclo deste procedimento (LUNARDI, 2013).

"Trata-se de controle abstrato porque seu objeto é um ato normativo ainda que não tenha produzido efeitos jurídicos, poderá a lei até mesmo ser questionada durante sua vacatio legis" (NERY JR.; ABBOUD, 2017, p. 651). Esse procedimento objetiva eliminar de nosso ordenamento jurídico quaisquer normas consideradas como sendo inconstitucionais (NERY JR.; ABBOUD, 2017).

Segundo Gilmar Ferreira Mendes (1990), esse processo de natureza objetiva é destinado, unicamente, à defesa dos interesses da Lei Suprema, e não à defesa dos interesses das partes, pois não pressupóe a defesa de situações subjetivas. Há, no controle abstrato de normas, um processo unilateral, sem partes, em que há requerente, mas inexiste requerido (MENDES, 1990).

Destina-se à interpretação constitucional, concebendo segurança jurídica e prevenindo violaçóes de normas constitucionais. Trata-se de preservar a supremacia da Constituição e não tutelar direitos ou interesses subjetivos (DIMOULIS; LUNARDI, 2013).

Com efeito, dispóe-se pelo controle abstrato "a declaração de inconstitucionalidade de um ato normativo em tese, neste caso por ação ou por omissão, independentemente da existência de uma lide" (FERREIRA, 2016, p. 53).

Sáo objetos desse processo objetivo as normas de direito federal ${ }^{29}$ ou estadual ${ }^{30}$.

Ademais, deve-se ressaltar que de modo contrário ao controle difuso, o controle abstrato produz efeito vinculante e erga omnes (NERY JR.; ABBOUD, 2017).

No Brasil, o controle incidental de constitucionalidade dos atos e omissóes do poder público pode operar-se - reafirmamos - no âmbito de qualquer demanda judicial, desde que exercido concretamente num processo inter partes, ao ensejo do desate de uma controvérsia, na defesa de direitos subjetivos de partes interessadas, onde se deseja a solução de um conflito de interesses. A questão da constitucionalidade somente é arguida incidentalmente, como prejudicial de mérito da pretensão deduzida, de modo que esta só pode ser desatada empós a resolução daquela conditio (JÚNIOR, 2010, p. 106).

29 Sendo consideradas como normas de direito federal: 1) as disposiçôes da lei fundamental; 2) as leis federais de qualquer espécie e conteúdo; 3) o regulamento editado pelo Governo Federal ou por um determinado Ministério Federal; 4) estatutos e regimentos editados pelas entidades autárquicas; 5) os atos normativos expedidos com fulcro no estado de necessidade legislativa (art. 81, da Lei Maior) e nas situaçôes de defesa (art. 115, alíneas "c" e "e", da Lei Fundamental); 6) o direito consuetudinário que é vigente em todo território nacional; 7) os acordos trabalhistas que possuem eficácia ampla e geral (MENDES, Gilmar Ferreira. Jurisdiçáo Constitucional: o controle abstrato de normas no Brasil e na Alemanha. 6. ed. São Paulo: Saraiva, 2014. p. $144-146)$.

30 Sendo consideradas como normas de direito estadual: 1) as disposiçôes das Constituiçôes Estaduais; 2) as leis estaduais; 3) as leis estaduais editadas para regulamentar matéria de competência exclusiva da Uniâo (art. 22, parágrafo único, CF/88); 4) decreto editado com força de lei; 5) o regimento interno dos Tribunais Estaduais e os regimentos das Assembleias Legislativas; 6) os atos normativos expedidos pelas pessoas jurídicas de direito público estadual (MENDES, Gilmar Ferreira. Controle Abstrato de Constitucionalidade: ADI, ADC e ADO: comentários à Lei n. 9.868/99. São Paulo: Saraiva, 2012. p . 132 - 133). 
Ainda, o controle abstrato de constitucionalidade corresponde "a um exercício atípico de jurisdição, pois nele não há um litígio ou propriamente, uma situação concreta a ser solucionada pela norma" (ROMANO, 2016, p. 153), e visa à retirada "do ordenamento jurídico um ato normativo (no todo ou em parte) declarado inconstitucional" (VAINER, 2009, p. 81 - 82). "Chama-se de abstrato porque seu objetivo, ao contrário de gerar efeitos para as partes dentro de um processo, gera efeitos gerais"(VAINER, 2009, p. 82), e, pode ser instaurado "independentemente da demonstração da existência de um interesse jurídico específico” (MENDES, 1994, p. 53), configurando típico processo objetivo.

Há, no controle abstrato de constitucionalidade: (a) a Ação Declaratória de Constitucionalidade; (b) a Ação Direta de Inconstitucionalidade por Ação; (c) Ação Direta de Inconstitucionalidade por Omissão; e (d) a Arguição de Descumprimento de Preceito Fundamental.

Enfim, o controle abstrato visa apenas à tutela do ordenamento jurídico, retirando-se qualquer norma ${ }^{31}$ inconstitucional, não pretendendo, destarte, resguardar o interesse das partes (VAINER, 2009).

Assim, pretende-se obter a declaração de inconstitucionalidade de um ato normativo, seja, neste caso, por ação ou por omissão (inconstitucional), independentemente da existência de uma lide.

\section{Da autonomia científica do controle abstrato de constitucionalidade}

Realizada análise acerca da fiscalização abstrata de constitucionalidade, e sua relação com a supremacia da Constituição, observa-se que o âmbito do presente estudo está relacionado ao processo objetivo. Todavia, não há consenso na doutrina ${ }^{32}$ se o direito processual constitucional abstrato possui autonomia científica.

Mesmo que parte da doutrina (CINTRA; DINAMARCO; GRINOVER, 1995; NERY JR, 2002; PÉREZ, 1980; DOMÍNGUEZ, 2006) compreenda que o direito processual constitucional abstrato não detém independência ${ }^{33}$, há doutrinadores que advogam pela autonomia científica da fiscalização abstrata de constitucionalidade (BERNARDES, 2004; CANAS, 1986; GOZAÍNI, 1995; FERREIRA, 2016; LUNARDI, 2013), por entenderem que

31 No todo, ou em parte.

32 Compreendem pela existência da autonomia científica do controle abstrato de constitucionalidade: BERNARDES, Juliano Taveira. Controle Abstrato de Constitucionalidade: elementos materiais e princípios processuais. São Paulo: Saraiva, 2004. p. 278 - 279; CANAS, Vitalino. Os Processos de Fiscalização da Constitucionalidade e da Legalidade pelo Tribunal Constitucional. Coimbra: Coimbra Editora, 1986. p. 87; GOZAÍNI, Osvaldo Alfredo. El Derecho Procesal Constitucional y los Derechos Humanos: vínculos y autonomías. México: Universidad Nacional Autónoma de México, 1995. p. 86; LUNARDI, Soraya. Teoria do Processo Constitucional: Análise de sua Autonomia, Natureza e Elementos. São Paulo: Atlas, 2013. p. 109 - 111. Em sentido contrário: CINTRA, Antônio Carlos Araújo; DINAMARCO, Cândido Rangel; GRINOVER, Ada Pellegrini. Teoria Geral do Processo. 11. ed. São Paulo: Malheiros, 1995. p. 79; NERY JR, Nelson. Princípios do Processo Civil na Constituição Federal. 7. ed. São Paulo: Revista dos Tribunais, 2002. p. 19; PÉREZ, Jesús González. Derecho Procesal Constitucional. Madrid: Civitas, 1980. p. 51 - 53.

33 Pois não passa de "mera colocação científica de um ponto de vista metodológico e sistemático, do qual se pode examinar o processo e suas relaçôes com a Constituição" (NERY JR, Nelson. Princípios do Processo Civil na Constituiçáo Federal. 7. ed. São Paulo: Revista dos Tribunais, 2002. p. 19). 
esta desenvolveu-se de maneira conexa com a atividade do Tribunal Constitucional, atendendo finalidades diversas daquelas previstas no processo tradicional (LUNARDI, 2013).

Nessa lógica, Lunardi explica que:

não é possível considerar o direito processual constitucional como parte do direito constitucional material. As normas constitucionais (substanciais) definem as formas de organização e as relações entre os poderes estatais, assim como entre o país e a comunidade internacional, os processos de produção de normas e o conteúdo dos direitos fundamentais. de seu lado, as normas processuais estabelecem critérios para a aplicação e garantia das prescriçôes do texto constitucional. O processo constitui uma das vias para assegurar a proteção do texto constitucional, dando vida a seu texto, através dos processos pertinentes (LUNARDI, 2013, p. 05 - 06).

Assim, com o intuito de justificar a disciplina autônoma do direito processual constitucional abstrato, faz-se desnecessária a subsistência de qualquer codificação específica (BERNARDES, 2004).

Entretanto, segundo Juliano Taveira Bernardes:

não se admite mais tratar o direito processual como direito "adjetivo", a emancipação de novo ramo dele há de decorrer da própria autonomia das regras processuais que lhe caracterizam o objeto de estudo, quando comparadas com as normas processuais que dizem respeito às outras divisôes do direito processual geral. Logo, para sustentar a emancipação do direito processual constitucional, não basta a autonomia disciplinar das noras que fundamentam a pretensão material por ele tutelada. É dizer: a autêntica emancipação disciplinar do direito processual constitucional depende da existência de conjunto próprio de regras e princípios processuais (BERNARDES, 2004, p. 278).

Por consequência, considerando que em muitos processos podem surgir questóes constitucionais, e que o sistema de fiscalização difuso de constitucionalidade autoriza sua resolução em qualquer grau de jurisdição sem a necessidade de instauração de novo processo, não há nexo em defender a autonomia do direito processual constitucional geral (BERNARDES, 2004).

"Isso porque tanto na seara do processo civil quanto na do processo penal, trabalhista, eleitoral ou militar poderá ser o órgão judicial convocado a exercer típica jurisdição constitucional" (BERNARDES, 2004, p. 278), sem que essa situação implique o exame de princípios e leis processuais próprias do direito processual destacado (BERNARDES, 2004).

Logo, a eventual autonomia científica do direito constitucional ${ }^{34}$ não será satisfatória para conceder caráter autônomo ao direito processual constitucional, se a interpretação e a aplicação de normas àqueles pertencentes não se der em processos também autônomos, perante às modalidades processuais abrangidas na área de estudo de outros ramos processuais (BERNARDES, 2004).

Por esse motivo, parte da doutrina (CINTRA; DINAMARCO; GRINOVER, 1995; NERY JR, 2002; PÉREZ, 1980; DOMÍNGUEZ, 2006) compreende que o direito processual constitucional não consiste em ramo autônomo do direito processual, nada obstante mera "colocação científica, de um ponto-de-vista metodológico e sistemático, do qual se pode examinar o processo em suas relações com a Constituição" (CINTRA; DINAMARCO; GRINOVER, 1995, p. 79).

34 Entenda-se aqui, direito processual constitucional material. 
Porém, salienta-se que essa assertiva é empregada apenas aos processos "por meio dos quais se implementa atividade ordinária de jurisdição constitucional; não aos processos da função jurisdicional especial de controle abstrato de constitucionalidade" (BERNARDES, 2004, p. 279).

Destarte, em decorrência do elevado número de peculiaridades no controle abstrato, constata-se que, nos processos em que há a efetivação da jurisdição constitucional em sentido estrito, o processo objetivo apresentará autonomia científica (BERNARDES, 2004).

Portanto, por consistir em procedimento especial de fiscalizaçáo abstrata de constitucionalidade, é dotado de autonomia científica. Essa, no processo objetivo, consiste na não utilização de normas de direito processual subjetivo à fiscalização abstrata de constitucionalidade, uma vez que essa é regida por regras e princípios próprios, que são necessariamente pouco fungíveis com os dos processos jurisdicionais típicos (CANAS, 1986).

Assim, em razão do caráter objetivo do controle abstrato de constitucionalidade, o próximo item deste trabalho buscará, minuciosamente, elucidar e identificar as principais singularidades desse procedimento especial.

\subsection{Do Processo Objetivo}

Em virtude da discussão referente ao controle de constitucionalidade do tipo abstrato, restou enfatizado o aspecto objetivo (D`AMICO, 1991) desse processo. Nesse sentido, o Supremo Tribunal Federal assegurou que, o controle abstrato, "em cujo âmbito instauram-se relaçôes processuais objetivas, visa-se a uma só finalidade: a tutela da ordem constitucional, sem vinculaçôes quaisquer a situaçôes jurídicas de caráter individual ou concreto"35.

Ainda, referindo-se ao controle abstrato de constitucionalidade, Hans Kelsen (2003) diz que esse procedimento de natureza objetiva processa-se com o fulcro de satisfazer o interesse público, fazendo jus a uma proteção por um processo correspondente à sua condição especial.

Depreende-se, portanto, que o significado de processo objetivo está diretamente relacionado ao controle abstrato de constitucionalidade, já que esse procedimento está associado a um interesse público-geral de esclarecimento normativo, com a exclusiva finalidade de tutela da supremacia da Constituição, autonomamente de quem solicitou o controle e de quem será beneficiado pela decisão da Suprema Corte (LUNARDI, 2013).

O processo objetivo é conceituado, tradicionalmente, como um procedimento em que não há contraditório ${ }^{36}$, sendo inexistentes as partes $^{37}$, destinado à defesa da Constituição (LUNARDI, 2013). Além disso, não há lide, entendida esta como conflito de interesses qualificado por uma pretensão resistida (TAVARES, 2005).

35 Agravo Regimental na ADI n. 203/DF, rel. Min. Celso de Mello, DJU de 20-4-1990, p. 3.048.

36 Não é observada a garantia do contraditório no processo objetivo pois argumenta-se que "os interessados e eventualmente afetados pela norma (ou a omissão normativa) impugnada compartilham do mesmo 'interesse diferenciado', que é a manutenção da ordem constitucional. Ora, não havendo interesses contrapostos, não é necessária a garantia do contraditório" (LUNARDI, Soraya. Teoria do Processo Constitucional: Análise de sua Autonomia, Natureza e Elementos. São Paulo: Atlas, 2013. p. 135).

37 Tradicionalmente, a definição de "parte", no processo, indica aquele que, com legítimo interesse, provoca a demanda ou nela se defende ou participa no exercício de interesse próprio (SILVA, Oscar Joseph Plácido e. Vocabulário Jurídico. v. II. Rio de Janeiro: Forense, 1991. p. 319). 
Gilmar Mendes caracteriza o processo objetivo como sendo:

destinado, pura e simplesmente, à defesa da Constituição ('Verfassungsrechtsbewahrungsverfahren'). Não se cogita, propriamente, da defesa de interesses do requerente ('Rechtsschutzbedürfnis'), que pressupõe a defesa de situaçóes subjetivas. Nesse sentido, assentou o Bundesverfassungsgericht que, no controle abstrato de normas, cuida-se fundamentalmente, de um processo unilateral, não contraditório, isto é, de um processo sem partes, no qual existe um requerente, mas inexiste requerido (MENDES, 1990, p. 251).

Na mesma linha, o Pretório Excelso compreende que, do ajuizamento de Ação Direta de Inconstitucionalidade, é instaurado processo objetivo em que não subsiste qualquer conflito referente à situação individual ou concreta ${ }^{38}$, em decorrência da ausência de partes que defendam interesses jurídicos próprios.

Esse entendimento é justificado pela existência de um interesse geral em preservar a supremacia das normas constitucionais, fato que seria inviável com a discussão de questôes subjetivas. Isto é, a decisão da Suprema Corte deve suceder-se de forma desvinculada de situaçóes e interesses concretos (LUNARDI, 2013).

O direito constitucional alemão dispõe, de maneira semelhante, sobre a definição de processo objetivo. Em 1952, o Tribunal Constitucional Federal ${ }^{39}$ afirmou que "o processo de controle de normas é objetivo, pois independe de interesses particulares, já que sua finalidade é tutelar a Constituição e não interesses de quem pede a sua realização" (LUNARDI, 2013, p. 28).

Assim sendo, há, no sistema alemão, "uma clara expressão da ideia que o processo constitucional realiza uma apreciação em abstrato, cotejando e comparando normas jurídicas" (LUNARDI, 2013, p. 116).

Nessa perspectiva, é notório o caráter objetivo do processo do controle abstrato de normas, pois: (a) o requerente atua em prol do interesse público, não alegando qualquer lesão a direitos, sejam eles próprios ou alheios (MENDES, 2012); (b) não há partes (MENDES, 2012), não sendo admissível, inclusive a participação de terceiros que exponham interesses individuais ou coletivos (LUNARDI, 2013); e (c) é destinado essencialmente à defesa da Constituição ${ }^{40}$.

Portanto, no processo objetivo, a fiscalização abstrata de constitucionalidade está vinculada a um interesse público de esclarecimento normativo ${ }^{41}$, "independentemente da pessoa ou autoridade que solicitou o controle e de quem será, de fato, beneficiado pela decisão da Corte" (LUNARDI, 2013, p. 116). Há, dessa maneira, um dever de controle de regularidade, o qual é diverso da tutela do interesse substancial de solucionar conflitos em casos concretos (TAVARES, 2001).

Logo, infere-se que o intuito do processo objetivo do controle abstrato de constitucionalidade consiste na confirmação, manutenção e certificação da supremacia da

38 Reclamação 397, questấo de ordem, medida cautelar, rel. Min. Celso de Mello, julgado em 25-11-1992.

39 "Nos termos do artigo 94 da Lei Fundamental da Alemanha, o Tribunal Constitucional Federal compóe-se de 16 juízes, dos quais 6 devem ter previamente atuado como juízes federais. A metade é eleita pelo Parlamento Federal (Bundestag), a outra metade pelo Conselho Federal, que é a representaçáo legislativa dos Estadosmembros" (LUNARDI, Soraya. Teoria do Processo Constitucional: Análise de sua Autonomia, Natureza e Elementos. Sáo Paulo: Atlas, 2013. p. 91).

40 Conforme: ADI 79, rel. Min. Celso de Mello, DJU de 12-9-1989.

$41 \mathrm{O}$ da tutela da Constituiçáo como finalidade exclusiva deste processo. 
Constituição, em objeção a quaisquer comportamentos, sejam esses normativos ou não, que da Carta Maior se desviem (TAVARES, 2005).

\subsection{Principio do Interesse Objetivamente Considerado}

Como no controle de constitucionalidade as garantias jurisdicionais comportam divisão entre garantias objetivas e subjetivas (MIRANDA, 1996), indaga-se se há a possibilidade, ou não, do uso de normas subjetivas na fiscalização abstrata de constitucionalidade, que consiste em típico processo de natureza objetiva.

"No regime de garantia subjetiva, a pretensão deduzida é a fruição de interesse ligado à satisfação de alguma necessidade, material ou imaterial, subjetivamente exprimível" (BERNARDES, 2004, p. 379). Por conseguinte, o interesse juridicamente tutelado é subjetivo.

Por sua vez, a demanda, nos instrumentos processuais de garantias objetivas, está diretamente relacionada à regularidade abstrata de observância do ordenamento jurídico (BERNARDES, 2004). "A tutela almejada não tem relação com a presença de nenhum interesse subjetivo juridicamente protegido, mas apenas com a preservação dos limites do exercício do poder estatal, conforme estabelecidos pelo constituinte" (BERNARDES, 2004, p. 379).

$\mathrm{O}$ interesse é objetivo por não incumbir à jurisdição qualquer tipo de satisfação, seja material ou imaterial, que seja justificável a atribuição a alguém, de maneira diferenciada dos demais membros da sociedade (BERNARDES, 2004).

Logo, entende-se que "não se discutem situaçóes individuais no âmbito do controle abstrato de normas, precisamente em face do caráter objetivo de que se reveste o processo de fiscalização concentrada de constitucionalidade" ${ }^{\prime 2}$.

Ademais, uma vez que ambos os institutos possuem regimes jurídicos próprios, não se mostra conveniente o emprego de normas processuais subjetivas a um processo objetivo, pois ocasionaria na utilizaçáo de normas processuais impertinentes e impróprias (TAVARES, 2010).

Portanto, compreende-se que o regime de garantias constitucionais objetivas "realiza-se à margem de um interesse pessoal, direto e legítimo na arguição da inconstitucionalidade. $\mathrm{O}$ que avulta é a constante conformidade das normas e dos actos com as normas constitucionais" (MIRANDA, 1996, p. 271). Essa é claramente a área de execução das normas e ações do controle abstrato de constitucionalidade (BERNARDES, 2004).

Pois bem. Considerandoaautonomia científica do controleabstrato deconstitucionalidade, em consequência do aspecto objetivo desse processo, resta visível o emprego do princípio do interesse objetivamente considerado.

Esse princípio explica que os interesses processuais são objetivos por não admitirem titularidade pessoal (BERNARDES, 2004). Desta maneira, não há sequer a demonstração de qualquer prejuízo a um indivíduo determinado ou a uma coletividade de pessoas, sejam determináveis ou não (BERNARDES, 2004). Ainda, exige a demonstração, na causa de pedir da respectiva ação de controle abstrato, de ato adverso ao interesse substancial objetivo de preservação da ordem constitucional (BERNARDES, 2004).

42 Nos termos: STF - Adin 1.254-MC-AgR, Rel. Min. Celso de Mello. 
Em hipótese alguma são defendidas situaçóes subjetivas de vantagem, sendo que a hipotética ilicitude que reclama intervenção judicial é explicada de maneira abstrata, sem o receio de solucionar uma situação concreta específica (BERNARDES, 2004).

\subsection{O Processo Objetivo na Jurisprudência do Supremo Tribunal Federal}

A investigação das decisóes do Supremo Tribunal Federal, quanto a aplicação a autonomia científica do controle abstrato de constitucionalidade é de suma importância, por conta das influências indevidas, que o direito processual constitucional de natureza objetiva recebe dos ramos do direito processual de natureza subjetiva (LUNARDI, 2013).

Favorável à tese da autonomia, já decidiu o Supremo Tribunal Federal ${ }^{43}$ que, em controle normativo abstrato, inexiste a aplicação prevista no artigo 188 do Código de Processo Civil de $1973^{44}$, sendo impossível que o prazo recursal seja computado em dobro, mesmo que a parte recorrente disponha, nos processos de índole subjetiva, de prerrogativa especial.

Em contrapartida, no Recurso Extraordinário com Agravo no 661.288, decidiu o Pretório Excelso que aplica-se, aos Recursos Extraordinários interpostos em Ações Diretas de Inconstitucionalidades no âmbito dos Tribunais de Justiça, o prazo em dobro do artigo 188 Código de Processo Civil de 1973. Destarte, observa-se que nesse caso o Supremo Tribunal Federal empregou norma processual subjetiva a um processo de natureza objetiva, contrariando a própria jurisprudência ${ }^{45}$.

Contudo, temos julgados em que a Suprema Corte $^{46}$ deixa explícita a presença da autonomia científica do controle abstrato de constitucionalidade, uma vez que esse procedimento possui natureza objetiva, e é destinado à defesa da supremacia da Constituição ${ }^{47}$.

Ademais, na Ação Direta de Inconstitucionalidade no 1.254/RJ, o Supremo Tribunal Federal destacou a importância de qualificar o controle normativo abstrato de constitucionalidade como processo objetivo, decidindo que a função processual do Advogado-Geral da União, nos processos de controle de constitucionalidade por via de ação, é extremadamente defensiva. Conforme o Pretório Excelso, o Advogado-Geral da Uniáo exerce, dentro da estrutura formal do processo objetivo, a posição de órgão agente, não lhe competindo opinar ou exercer função fiscalizadora já atribuída ao Procurador-Geral da República ${ }^{48}$.

43 ADI no 1.797/PE; ADI no 2.130/SC; STF - ARE no 827511/PR.

44 "Art. 188, CPC/73: Computar-se-á em quádruplo o prazo para contestar e em dobro para recorrer quando a parte for a Fazenda Pública ou o Ministério Público".

45 ADI no 1.797/PE; ADI no 2.130/SC; STF - ARE no 827511/PR; AI no 633.998/RS; RE no 579.760/RS; AI $n^{\circ}$ 788.453/SC; RE no 375.525/MG; AI no 555.860/MG.

46 Conforme: STF - ARE: 827511/PR, rel. Min. Celso de Mello, data de julgamento: 21/10/2014; ADI no 2.422/DF, rel. Min. Celso de Mello, data de julgamento: 10/05/2012; ADI no 1.254/RJ, rel. Min. Celso de Mello, data de julgamento: 14/08/1996; ADI no 3.345/DF, rel. Min. Celso de Mello, data de julgamento: 25/08/2005.

47 Nesse sentido, na Ação Direta de Inconstitucionalidade no 2.971/RO, o Supremo Tribunal Federal ratificou que o controle abstrato de constitucionalidade consiste em instrumento de preservação da integridade jurídica da ordem constitucional vigente.

48 Conforme a ADI no 1616-4/PE, destaca-se que a atuação do Advogado Geral da Uniâo será dispensada em apenas uma única hipótese, em se tratando de processos de Ação Direta de Inconstitucionalidade por Ação: caso já houver decisão do Supremo Tribunal Federal sobre a inconstitucionalidade da norma. 
Além disso, a autonomia científica do controle abstrato de constitucionalidade é ratificada no julgamento da Açáo Direta de Inconstitucionalidade no 3.345/DF, pois o Supremo Tribunal Federal, nesse processo, deliberou que os institutos do impedimento e da suspeição restringemse ao plano dos processos subjetivos. Desta maneira, segundo a Suprema Corte, mesmo que o Presidente do Tribunal Superior Eleitoral preste informaçóes no processo de controle de constitucionalidade, não estará impedido de participar de seu julgamento.

Entretanto, há decisão monocrática do Ministro Dias Toffoli na Ação Direta de Inconstitucionalidade $n^{\circ} 5452 / \mathrm{DF}$ que determinou que o requerente emende a petiçáo inicial, sob pena de extinção da mesma, nos termos do artigo 321, parágrafo único, do Código de Processo Civil de $2015^{49}$, o qual é inaplicável ao controle abstrato, diante da sua autonomia científica.

Em decisão monocrática da Ministra Rosa Weber na Ação Direta de Inconstitucionalidade $\mathrm{n}^{\mathrm{o}} 3.406 / \mathrm{RJ}$, que fundamentando-se no poder geral de cautela (artigos 297, 932, II, 995, parágrafo único, e 1.026, $\$ 1^{\mathrm{o}}$, do Código de Processo Civil de $2015^{50}$ ), deferiu pedido para suspender parcialmente os efeitos da decisão referentes a atribuição de eficácia erga omnes à declaração de inconstitucionalidade do artigo $2^{\circ}$ da Lei no 9.055/1995, até a publicação do acórdão respectivo e da fluência do prazo para a oposição de embargos de declaração.

Esta decisão monocrática proferida, modula os efeitos da declaração de inconstitucionalidade, ao arrepio do quórum legal de dois terços dos membros do Tribunal ${ }^{51}$, aplicando, de modo inadequado ${ }^{52}$, norma processual subjetiva prevista no Código de Processo Civil de 2015 ao controle abstrato de constitucionalidade, afastando norma expressa desta modalidade de controle.

Nesse sentido, em decisão monocrática, na Ação Direta de Inconstitucionalidade $\mathrm{n}^{\circ}$ 1.814/DF53, o Ministro Maurício Corrêa decidiu que regras instrumentais destinadas aos procedimentos de natureza subjetiva náo devem ser aplicadas ao controle normativo abstrato, pois corresponde a um processo de natureza objetiva que está sujeito a disciplina processual própria ${ }^{54}$.

$49 \mathrm{CPC} / 2015$, "Art. 321. O juiz, ao verificar que a petição inicial não preenche os requisitos dos arts. 319 e 320 ou que apresenta defeitos e irregularidades capazes de dificultar o julgamento de mérito, determinará que o autor, no prazo de 15 (quinze) dias, a emende ou a complete, indicando com precisão o que deve ser corrigido ou completado. Parágrafo único. Se o autor não cumprir a diligência, o juiz indeferirá a petição inicial”.

50 "A teor do art. 932 do CPC/2015, incumbe ao relator apreciar o pedido de tutela provisória nos recursos e nos processos de competência originária do tribunal. O art. 995, parágrafo único, do CPC/2015, a seu turno, autoriza o relator a suspender a eficácia da decisão recorrida, "se da imediata produção de seus efeitos houver risco de dano grave, de difícil ou impossível reparação”, e, por último, o seu art. 1.026, $\ 1^{\circ}$, é expresso ao permitir a suspensão da eficácia da decisão colegiada, pelo relator dos embargos de declaração, "se houver risco de dano grave ou de difícil reparação", decisão monocrática da Min. Rosa Weber, em 19 de dezembro de 2017, na Ação Direta de Inconstitucionalidade no 3.406/RJ .

51 Art. 27 da Lei no 9.868/99.

52 Contrariando a própria jurisprudência do STF, conforme: ADI no 1.797/PE; ADI no 2.130/SC; STF - ARE nº 827511/PR; AI no 633.998/RS; RE no 579.760/RS; AI no 788.453/SC; RE no 375.525/MG; AI no 555.860/ MG.

53 Nesse caso, o signatário da inicial atuou na estrita condição de representante legal do ente federado (nos termos do artigo 12, I, do CPC de 1973), e não do Governador de Estado, sendo essas, portanto, pessoas que não se confundem.

54 Constituição Federal e Lei n no 9.868/99. 
Portanto, pelo exame desses julgados ${ }^{55}$, observa-se a presença da autonomia científica do controle abstrato de constitucionalidade, pois do ingresso de ação desse procedimento, é instaurado processo objetivo em que não subsiste qualquer conflito referente à situação individual ou concreta ${ }^{56}$.

Logo, depreende-se que o Supremo Tribunal Federal emprega uma concepçáo sistêmica atomista ou mecanicista ${ }^{57}$, visto que esse órgão de cúpula do Poder Judiciário preza pela especificidade da fiscalização abstrata de constitucionalidade, em virtude da independência desse processo de natureza objetiva das normas processuais subjetivas.

\section{Consideraçóes finais}

O controle abstrato de constitucionalidade corresponde a um processo de natureza objetiva, que tem por finalidade a defesa da ordem constitucional, não estando vinculado a qualquer situação jurídica de caráter individual ou concreto. Nesse procedimento não há partes, e, em tese, inexiste uma lide. Por conseguinte, não há a observância ao princípio do contraditório.

Ademais, no controle normativo abstrato, os interesses processuais são exclusivamente objetivos, não sendo admitida qualquer titularidade desses. Logo, não se mostra conveniente o emprego de normas subjetivas a um processo objetivo, pois ocasionaria na utilização de normas processuais impertinentes e, consequentemente, impróprias.

Desta maneira, em razão da objetividade do controle abstrato, observa-se o emprego o princípio do interesse objetivamente considerado nesse procedimento. Esse princípio explica que, no processo abstrato, os interesses processuais sáo objetivos por não permitirem titularidade processual. Assim, não se mostra possível verificar qualquer prejuízo a um indivíduo determinado ou a uma coletividade (in)determinada.

Posto a especificidade e a consequente independência do processo objetivo das normas processuais subjetivas, constata-se a existência da autonomia científica da fiscalização abstrata de constitucionalidade. Esse é o entendimento adotado pelo Supremo Tribunal Federal, conforme o julgado nas Açóes Direitas de Inconstitucionalidade no 1.254/RJ, no 3.345/DF e no 2.422/DF.

Segundo o Pretório Excelso, nos referidos julgados, a autonomia científica do controle abstrato se justifica pela ciência atomista ou mecanicista do processo objetivo, já que esse procedimento é regido por regras e princípios próprios, que não são fungíveis com os dos processos jurisdicionais subjetivos.

Em suma, em razão do caráter objetivo, e em decorrência da especificidade e do elevado número de peculiaridades do controle abstrato de constitucionalidade, é possível concluir que esse procedimento é dotado de autonomia científica.

55 ADI no 1.814/DF; ADI no 1.797/PE; ADI no 2.130/SC; STF - ARE no 827511/PR; STF - ARE: 827511/ PR, rel. Min. Celso de Mello, data de julgamento: 21/10/2014; ADI no 2.422/DF, rel. Min. Celso de Mello, data de julgamento: 10/05/2012; ADI no 1.254/RJ, rel. Min. Celso de Mello, data de julgamento: 14/08/1996; ADI no 3.345/DF, rel. Min. Celso de Mello, data de julgamento: 25/08/2005.

56 Reclamação 397, questão de ordem, medida cautelar, rel. Min. Celso de Mello, julgado em 25-11-1992

57 A concepção atomista ou mecanicista consiste em um sistema em que os fenômenos da científicos são analisados como partes (entidades atômicas) e processos isolados (BERTALANFFY, Ludwig von. Teoria Geral dos Sistemas: fundamentos, desenvolvimento e aplicaçôes. Tradução de Francisco M. Guimarães. 8. ed. Petrópolis/ RJ: Vozes, 2015. p. $54-55)$. 


\section{Referências}

BARROSO, Luís Roberto. O Controle de Constitucionalidade no Direito Brasileiro. 7. ed. rev. e atual. São Paulo: Saraiva, 2016.

BERNARDES, Juliano Taveira. Controle Abstrato de Constitucionalidade: elementos materiais e princípios processuais. São Paulo: Saraiva, 2004.

BERTALANFFY, Ludwig von. Teoria Geral dos Sistemas: fundamentos, desenvolvimento e aplicações. Tradução de Francisco M. Guimarães. 8. ed. Petrópolis/RJ: Vozes, 2015.

BONIZZI, Marcelo José Magalhães; FERREIRA, Olavo Augusto Vianna Alves. Declaração de Inconstitucionalidade pelo Árbitro: Vedação ou Dever. Revista de Processo, v. 274, p. 543 578, dez. 2017.

CALCINI, Fábio Pallaretti. Limites ao Poder de Reforma da Constituiçáo: o embate entre as geraçóes. Campinas: Millennium Editora, 2009.

CANAS, Vitalino. Os Processos de Fiscalizaçáo da Constitucionalidade e da Legalidade pelo Tribunal Constitucional. Coimbra: Coimbra Editora, 1986.

CANOTILHO, J. J. Gomes. Direito Constitucional e Teoria da Constituiçáo. 7. ed. Coimbra: Almedina, 2007.

CINTRA, Antônio Carlos Araújo; DINAMARCO, Cândido Rangel; GRINOVER, Ada Pellegrini. Teoria Geral do Processo. 11. ed. São Paulo: Malheiros, 1995.

CLÈVE, Clèmerson Merlin. A Fiscalização Abstrata da Constitucionalidade no Direito Brasileiro. 2. ed. rev., atual. e ampl. São Paulo: Revista dos Tribunais, 2000.

D`AMICO, Marilisa. Parti e Processo nella Giustizia Costituzionale. Torino: G. Giappichelli, 1991.

DIMOULIS, Dimitri; LUNARDI, Soraya. Curso de Processo Constitucional: controle de constitucionalidade e remédios constitucionais. 2. ed. São Paulo: Atlas, 2013.

DOMÍNGUEZ, Elvito Rodríguez. Derecho Procesal Constitucional. Lima: Grijley, 2006.

FERREIRA, Olavo Augusto Vianna Alves. Controle de Constitucionalidade e seus Efeitos. 3. ed. rev. e atual. Salvador: Juspodivm, 2016.

GODOY, Arnaldo Sampaio de Moraes. Direito nos Estados Unidos. Barueri: Manole, 2004.

GOZAÍNI, Osvaldo Alfredo. El Derecho Procesal Constitucional y los Derechos

Humanos: vínculos y autonomías. México: Universidad Nacional Autónoma de México, 1995.

HESSE, Konrad. A Força Normativa da Constituição. Tradução de Gilmar Ferreira Mendes. Porto Alegre: SAFE, 1991. 
JÚNIOR, Dirley da Cunha. Controle de Constitucionalidade: Teoria e Prática. 4. ed. rev., atual. e ampl. Salvador: Juspodivm, 2010.

KELSEN, Hans. Jurisdição Constitucional. São Paulo: Martins Fontes, 2003.

KELSEN, Hans. Teoria Pura do Direito. São Paulo: Martins Fontes, 1987.

LUNARDI, Soraya. Teoria do Processo Constitucional: Análise de sua Autonomia, Natureza e Elementos. São Paulo: Atlas, 2013.

MARIA, Regina; MACEDO, Nery Ferrari. Efeitos da Declaraçáo de Inconstitucionalidade. 4. ed. rev., atual. e ampl. São Paulo: Revista dos Tribunais, 1999.

MARTINS, Leonardo. Direito Processual Constitucional Alemáo. 2. ed. rev., atual. e ampl. Indaiatuba/SP: Editora Foco, 2018.

MENDES, Gilmar Ferreira. A Açáo Declaratória de Constitucionalidade: a inovação da Emenda Constitucional n. 3 de 1993. São Paulo: Saraiva, 1994.

MENDES, Gilmar Ferreira. Controle Abstrato de Constitucionalidade: ADI, ADC e ADO: comentários à Lei n. 9.868/99. São Paulo: Saraiva, 2012.

MENDES, Gilmar Ferreira. Controle de Constitucionalidade: aspectos jurídicos e políticos. São Paulo: Saraiva, 1990.

MENDES, Gilmar Ferreira. Jurisdiçáo Constitucional: o controle abstrato de normas no Brasil e na Alemanha. 6. ed. Sáo Paulo: Saraiva, 2014.

MIRANDA, Jorge. Contributo para uma Teoria da Inconstitucionalidade. Coimbra: Coimbra Editora, 1996.

MORAES, Alexandre de. Direito Constitucional. 15. ed. São Paulo: Atlas, 2004.

NERY JR., Nelson. Princípios do Processo Civil na Constituiçáo Federal. 7. ed. São Paulo: Revista dos Tribunais, 2002.

NERY JR., Nelson; ABBOUD, Georges. Direito Constitucional Brasileiro. São Paulo: Revista dos Tribunais, 2017.

PÉREZ, Jesús González. Derecho Procesal Constitucional. Madrid: Civitas, 1980.

POLLETI, Ronaldo. Controle de Constitucionalidade das Leis. Rio de Janeiro: Forense, 1985.

RAMOS, Elival da Silva. A inconstitucionalidade das Leis: vício e sanção. São Paulo: Saraiva, 1994.

ROMANO, Rodrigo Ribeiro. A Atuaçáo do Legitimado Ativo no Controle Abstrato de Constitucionalidade: Critérios Procedimentalistas para a Propositura da Ação no Contexto de Lutas por Reconhecimento. 2016. 231 f. Dissertação apresentada como requisito parcial à 
obtenção do título de Mestre em Direito. Faculdade de Direito, Universidade Federal do Rio Grande do Norte, Natal, 2016.

SILVA, José Afonso da. Curso de Direito Constitucional Positivo. 36. ed. rev. e atual. São Paulo: Malheiros, 2013.

SILVA, José Afonso da. Proteção Constitucional dos Direitos Humanos no Brasil: evolução histórica e direito atual. Revista da Procuradoria Geral do Estado de Sáo Paulo, edição especial em comemoração dos 10 anos da Constituiçáo Federal, set. 1998. p. 173.

SILVA, Oscar Joseph Plácido e. Vocabulário Jurídico. v. II. Rio de Janeiro: Forense, 1991.

SIQUEIRA JR., Paulo Hamilton. Direito Processual Constitucional. 7. ed. São Paulo: Saraiva, 2017.

TAVARES, André Ramos. Curso de Direito Constitucional. 8. ed. rev. e atual. São Paulo: Saraiva, 2010.

TAVARES, André Ramos. Teoria da Justiça Constitucional. São Paulo: Saraiva, 2005.

TAVARES, André Ramos. Tratado da Arguição de Preceito Fundamental. São Paulo: Saraiva, 2001.

TEMER, Michel. Elementos de Direito Constitucional. 14. ed. rev. e ampl. São Paulo: Malheiros, 1998.

VAINER, Bruno Zilberman. A Pertinência Temática e o Controle Concentrado de Constitucionalidade: o Interesse de Agir à Luz do Papel do Supremo Tribunal Federal como Guardião da Constituiçáo. 2009. 311 f. Dissertação apresentada como requisito parcial à obtenção do título de Mestre em Direito. Faculdade de Direito, Pontifícia Universidade Católica - PUC/SP, São Paulo, 2009.

VELOSO, Zeno. Controle Jurisdicional de Constitucionalidade. 3. ed. atual. e ampl. Belo Horizonte: Del Rey, 2003.

ZAVASCKI, Teori Albino. Eficácia das Sentenças na Jurisdição Constitucional. 4. ed. rev. atual. e ampl. São Paulo: Editora Revista dos Tribunais, 2017.

ZAVASCKI, Teori Albino. Processo Coletivo: Tutela de Direitos Coletivos e Tutela Coletiva de Direitos. 7. ed. rev. atual. e ampl. São Paulo: Editora Revista dos Tribunais, 2017. 